\title{
Needy or Greedy? The Social Psychology of Individuals Who Fraudulently Claim Unemployment Benefits'
}

\author{
D. J. HESSING ${ }^{2}$ AND H. ElFFERS \\ Faculty of Law, Erasmus University Rotterdam \\ H. S. J. ROBBEN \\ Department of Industrial Design, Delft University of Technology \\ P. WEBLEY \\ Department of Psychology, University of Exeter
}

\begin{abstract}
This study explored the relationships between diverse social psychological and economic variables and self-reported and officially documented unemployment benefit fraud. Two groups receiving unemployment benefit were studied; a fraudulent group of 45 individuals and an honest group of 51 individuals. Interview measures of financial strain, social norms, opportunity for fraud, social controls, personal strain, personal orientation, perceived risk of punishment, and intolerance of fraud were obtained. The results of univariate and regression analyses revealed that although financial strain and social norms did not differ between the two groups, the fraudulent group had more opportunity, were less well educated, were more alienated and inclined to take risks, and had more positive attitudes toward a variety of kinds of fraud.
\end{abstract}

Over the past decade social psychologists have become increasingly interested in economic behavior and there is now an extensive literature on topics such as unemployment (Kelvin \& Jarrett, 1985), tax evasion (Friedland, 1985; Hessing, Elffers, \& Weigel, 1988), and saving (Furnham, 1985b; Webley, Levine, \& Lewis, 1991). But surprisingly, given the extensive media coverage of social security fraud (Golding \& Middleton, 1978, 1982) and public interest in the topic, this issue has been almost completely neglected.

It is crucial at the outset to put social security fraud in perspective. Despite widespread beliefs to the contrary, social security fraud appears to be neither extensive nor expensive, though obviously there is considerable variation from one country to another and it is hard to obtain reliable figures. According to Smith (1986) in Great Britain far more money is saved in unclaimed

\footnotetext{
We would like to thank the Federatie van Bedrijfsverenigingen (FBV) for their financial support and help with this research.

${ }^{2}$ Correspondence concerning this article should be addressed to Professor D. J. Hessing, Erasmus Centre for Socio-legal Tax Research, Faculty of Law, Erasmus University Rotterdam, P.O. Box 1738, NL-3000 DR Rotterdam, The Netherlands.
} 
benefits than is lost in fraud, and from U.S. data it can be estimated that in $1986 \$ 235$ million dollars were fraudulently obtained through unemployment benefit compared to $\$ 70$ billion of income not reported to the tax authorities (Kingston, Burgess, \& St. Louis, 1981, 1986; Roth, Scholz, \& Witte, 1989). From the large-scale survey research by Kazemier, van Eck, and Koopmans (1990) it appears that benefit fraud is more prevalent in the Netherlands than in Britain or America. One survey revealed a 13\% participation in the black economy overall (with $17 \%$ of those receiving benefits participating); the other found a $26 \%$ participation rate overall (with $28 \%$ of those receiving benefits participating). These surveys lead to an estimate that of the approximately 2 million people receiving benefits in 1986, between 300 and 600 thousand earned money on the side. The vast majority of these earned less than 1,500 guilders $(\$ 700)$ a year from this activity.

The obvious question then is why do some people fraudulently claim unemployment benefits? The simplest answer is that the motivation is economic. As one of the social security investigators interviewed by Loveland (1989) put it, "I could understand it if there was desperation . . but with these people it is greed not need." At the heart of Yaniv's (1986) theoretical analysis of fraudulent collection of unemployment benefits there is an assumption that people will defraud the authorities when it pays them to do so. If the perceived rewards of fraud outweigh the perceived costs then, given the opportunity, individuals will act fraudulently. This economic model has failed to account adequately for the similar behavior of evading taxes (where, as Smith and Kinsey (1987) point out, this kind of approach would predict that virtually everybody should be evading taxes) and seems unlikely to be any more successful in explaining benefit fraud.

The tax evasion field provides a rich source of social psychological models on which to base an explanation of benefit fraud (for a review of models, see Hessing, Kinsey, Elffers, \& Weigel, 1988). Here we propose to use the model of Weigel, Hessing, and Elffers (1987), which treats tax evasion as defective behavior within a social dilemma. Just as the tax system confronts people with a choice between cooperative behavior (paying taxes in full) and defective behavior (evading some or all taxes) so does the social security system. Here the choice is between cooperating (obeying the rules and if working on the side reporting the extra income) or defecting (breaking the rules and doing extra paid work without reporting it). Individuals would be better off if they broke the rules but the whole system would break down if it was abused by all.

Conceiving a person in receipt of unemployment benefit as being part of a social dilemma immediately draws attention to the motivational orientation of individuals, as this has long been a focus of social dilemma research (Liebrand, Messick, \& Wilke, 1991). Is a person cooperative, individualistic, 
or competitive? But individual differences, though an important part of the model, are only part of it. The framework (presented in Figure 1) specifies two kinds of variables: instigations and constraints. These variables are found both in the individual and in the situation with which he or she is confronted. For example, social norms that stress wealth as a measure of status have their parallel in personal orientations that are self-serving rather than altruistic. Instigations operate in the early stage of the process of contemplating benefit abuse whereas constraints come into play at a later stage. After feeling instigated to do some work on the side (perhaps because of financial strain), people then start to think about the constraints and will be worried if the constraints are seen as severe or reassured if they are lacking.

In their more general approach to social dilemmas, Hessing and Elffers (1985) have produced a social-orientation meta-model that specifies the situations under which different kinds of variables will predict behavior in a social dilemma. The important point in this context is the distinction between public and private acts. According to Hessing and Elffers, norms will have an influence on behavior only if that behavior is public and visible; by contrast central attitudes (e.g., social orientation) will be much more relevant with private behavior. The relevance of this to tax evasion and benefit fraud is that although evasion and fraud are private acts they are often measured publicly (through self-report). This predicts that selfreported evasion and fraud may be predicted by rather different variables than actual evasion.

In the tax evasion field this model has performed well. For example, Elffers, Weigel, and Hessing (1987) measured the self-reported behavior and officially documented behavior of two groups of Dutch taxpayers (one group of definite evaders, the other group of honest taxpayers) and found a neglible correlation between the two measures. Personal constraint measures (e.g., fear of punishment, attitudes toward tax evasion) were correlated with self-reported behavior but unrelated to documented behavior. Conversely, personal instigation measures (e.g., social motivation, alienation) were correlated with documented behavior but not self-reported behavior.

The paucity of psychological research into benefit fraud makes it hard to judge the model's value in this field. Two studies however, provide some pointers, those of Renooy (1990) and Elffers and Hessing (1990).

Renooy (1990) explored the motives, background, and circumstances that lead to participation in the "twilight" economy. He identified structural factors which pressured, and opportunity factors which encouraged, people to participate in the twilight economy. For a third of his respondents serious financial problems were the most important reason for participation. For this group their illegal income provided at least $40 \%$ of their overall income and enabled them to keep their heads above water. A number of opportunity 


\section{SOCIAL CONDITIONS Situational Instigations \\ 1. Financial strain (monthly income) \\ 2. Social Norms (perceived incidence of fraud, norms for fraudulent behaviour) \\ Situational Constraints \\ 1. Opportunity (opportunity for fraud in occupational group) \\ 2. Legal controls \\ 3. Social Controls (frequency of fraud in occupational group)}

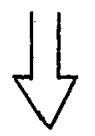

PSYCHOLOGICAL CONDITIONS Personal instigations

1. Personal strain

(comparison of benefit with previous earnings, satisfaction with household situation)

2. Personal orientation

(Competitive social

orientation, alienation)

Personal constraints

1. Perceived opportunity

2. Perceived risk of punishment (certainty of being caught, severity of punishment)

3. Intolerance of fraud (moral beliefs about fraud)

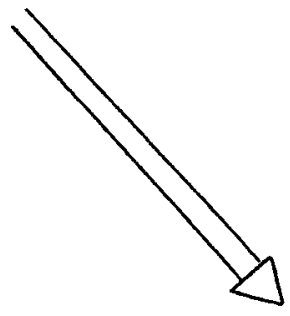

SOCIAL SECURITY FRAUD

1. Officially measured behaviour

2. Self-reported behaviour

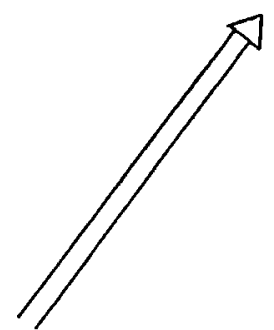

Figure 1. A social psychological model of unemployment benefit fraud (adapted from Weigel, Hessing, \& Elffers, 1987). Examples of the variables in the model are included in brackets. 
factors were also important. Participation in the twilight economy was associated with appropriate skills, better education, supportive cultural standards, and positive attitudes toward participation.

Although the sample size is small (and includes many who are not engaging in fraud), this certainly suggests that the Weigel et al. (1987) model is plausible, though it is predictable that respondents should mention financial strain.

The results of the Elffers and Hessing (1990) study are less self-evident. They put questions on benefit fraud and evasion to a large tele-interview panel, which consists of people who in return for a $\mathrm{PC}$ are required to answer each week a series of questions on a variety on topics presented to them on the micro-computer. Three of the questions concerned whether the respondent had done any moonlighting over the past year, whether they had evaded taxes, and whether they had done work on the side while receiving unemployment benefit. These questions were put on different occasions. What was striking was that all these behaviors correlated significantly; there was a particularly high correlation between benefit fraud and moonlighting (.42). These behaviors also correlated with competitiveness. This suggests that those individuals who fraudulently claim unemployment benefit are not so much unemployed who have strayed, rather that they are habitually make use of whatever opportunity arises. If they are receiving unemployment benefit then that is working on the side, if they have a proper job it is moonlighting and tax evasion.

These results certainly provide some support for the Weigel et al. (1987) model (in that personal orientation is implicated). To go further requires a full-scale study as reported below. This sets out to explore the relationships between diverse social psychological and economic variables and selfreported and officially documented benefit fraud. Based on the tax evasion research we predict that personal constraint measures will predict selfreported fraud but be unrelated to documented fraud. Conversely, personal instigation measures will be correlated with documented fraud but not selfreported fraud. As in the Elffers et al. (1987) study a contrast design was employed with one group that were officially classified as having fraudulently claimed benefit and the other group being officially classified as honest.

\section{Method}

\section{Background: The Dutch Unemployment Benefit System}

People employed in the private sector, as well as their employers, pay a percentage of their earnings as unemployment allowance premium. If they 
lose their jobs (through no fault of their own) they may claim unemployment benefit for up to a year. They must actively look for work and report once a week on their progress. If they earn anything during this period this must be reported to the agency so that their benefit may be lowered proportionately (for more details see Social Security News, 1987).

Our concern is with individual benefit fraud, which occurs when an employee has a paid job and still claims benefit. If this is detected, the fraudulent claimant will be given a bill for the amount overpaid and will lose his benefit. If the defrauded amount is greater than a certain threshold, the claimant will face criminal proceedings.

\section{Subjects and Procedure}

The contrast groups (fraudulent, honest) were set up by the regional offices of the Federatie van Bedrijfsverenigingen (Federation of Industrial Insurance Boards). The fraudulent group were compiled from the files of the agency's Fraud Investigation Division. They were asked to look for cases which met the following description:

People who have incorrectly claimed an unemployment benefit. The investigator must have no doubt about the intention to defraud. It should have occurred in 1985, 1986, or 1987, concern an amount of at least f1000 (approximately $\$ 500$ ) fraudulently obtained benefit money and have been sent to the public prosecutor.

The honest group was drawn from the general files of the agency and consisted of people who had drawn an unemployment benefit in 1985, 1986, and 1987 and about whom there was no reason to be suspicious.

To protect the privacy of the respondents a procedure similar to that used by Elffers et al. (1987) was employed. Briefly, this involved the use of an independent third party, to ensure that at no time did the agency, the third party or the researchers have all the information about an individual (name and address, official data, interview data). The agency only ever knew the name, address, and official data and the researchers obtained, finally, the official data coupled with the interview data but without names and addresses (for more details of this procedure see Robben, Elffers, \& Verlind, 1989).

The agency was able to select 376 cases in the honest group and 343 in the fraudulent group. These people were then asked, through a series of letters from the university, if they would take part in an interview study of opinions about tax and social security. This series of letters were constructed follow- 
ing Dillman's Total Design Method (1978) because of worries that the response rate might be low. Thus everyone received the first two letters, an initial letter that stressed the importance of people participating in order to obtain an accurate picture followed by a reminder a week later. Those who had not replied received after a week another letter and, after an interval of a further 2 weeks, those who had still not replied received a registered letter. Despite this the response was poor. Overall $26 \%$ agreed to participate (106 in the honest group, 76 in the fraud group), $40 \%$ never responded, $18 \%$ had moved or died, and $11 \%$ refused (most of these after the fourth mailing). Of these 96 people were interviewed, 51 in the honest group ( 34 men, 14 women) and 45 in the fraudulent group ( 42 men, 3 women).

Using data supplied by the agency it was possible to compare the respondents with the nonrespondents on certain characteristics. There were no significant differences between respondents and nonrespondents or between the honest and fraudulent group for salary per month, number of hours worked and benefit per month. More importantly for the fraudulent group there were no significant differences between the respondents and nonrespondents for duration of fraud, estimated total amount of fraud, whether the person concerned was a first offender, sanctions applied in the past, and the agency's estimate of the frequency of fraud in the occupational group.

\section{Dependent Measures}

The dependent measures were of two kinds. The vast majority were derived from interviews which were carried out in the respondent's own homes by research assistants and which lasted, on average, 2 hours. The interviews were very highly structured and essentially consisted of taking the respondents through a long questionnaire ensuring that no questions were omitted. The remaining measures were derived from the unemployment agency. The dependent measures are described here according to their place in the model; this was not the order followed in the interview. The description given here is necessarily succinct; full details of the dependent measures can be found in Hessing, Elffers, Robben, and Webley (1991).

\section{Situational Instigations}

Financial strain. The interview asked for net income prior to receiving unemployment benefit, amount of unemployment benefit, and a self-classification of income group.

Social norms. Social Norms were assessed in three ways (a) using measures of disapproval of unemployment in the neighborhood (b) measuring 
the estimated incidence of benefit fraud (c) using questions that explored the attitudes of others to benefit fraud.

\section{Situational Constraints}

Opportunity. Twenty one unemployment agency officials were given a list of 91 occupations and asked to estimate how easy it was to earn money on the side in each occupation. Their mean estimates were used as the measure of opportunity.

Social controls. Frequency of fraud in the occupational group of each respondent was estimated by officials in the unemployment agency.

\section{Personal Instigations}

Personal strain. Respondents gave a comparison of unemployment benefit with previous income and with the minimum wage in Holland and indicated their satisfaction with their household economic situation (a scale with an alpha of .79), their view of the perceived level of benefit (a scale with an alpha of .75), and their view of the perceived fairness of social security rules (a scale with an alpha of .73).

Personal orientation. A large number of measures of personal orientation were used, most of which were well established scales. Social orientation was measured using the decomposed games method employed by Liebrand (1982) and McClintock and Allison (1989). Based on their choices people were classified as altruistic (score 1), cooperative (score 2), individualistic (3), or competitive (4). Free-rider behavior was assessed using items concerned with behavior such as blood donation and energy saving taken from Condie, Warner, and Gillman (1976). Risk-taking was measured using the relevant scale (alpha $=.72)$ from the Jackson Personality Inventory (Jackson, 1976). Alienation was measured using the scales of Zeller, Neal, and Groat (1980). Disinhibition was assessed using Hauber, Toornvliet, and Willemse's (1986) scale (alpha $=.76$ ) which is based on Zuckerman's (1979) sensation-seeking scale. The Protestant Work Ethic was assessed with 11 items taken from Mirels and Garett (1971). Single measures of the perceived exchange relationship with government and horizontal equity were also used.

\section{Fersonal Constraints}

Perceived opportunity. Perceived opportunity of fraud was measured using a single item.

Perceived risk of punishment. Respondents were presented with hypothet- 
ical situations involving fraud and asked to estimate the likelihood of being caught and the likely severity of punishment if caught.

Intolerance of fraud. Attitudes toward unemployment benefit fraud and attitudes toward social security fraud were both measured in the same way using five semantic differentials. Attitude toward tax and benefit fraud was measured using a 10-item Likert scale with an alpha of .79. Attitude toward abuse of the social security system was a 4 -item scale based on that on Furnham (1985a).

\section{Other Variables}

Demographics. Respondents were asked for information about sex, age, occupation, and educational level.

Self-reported fraud. Toward the end of the interview respondents were asked "In the past two years have you earned money on the side when receiving unemployment benefit?"

Other. Respondents were asked about their experience of unemployment. The imaginability of oneself evading taxes was measured using a variant of Newman's (1976) scale of crime seriousness. Respondents had to rank order 10 illegal acts according to their seriousness, and then indicate the most serious crime they could imagine committing. In addition there were some questions about their knowledge of the social security system and a number of other questions (e.g., concerning their intention to work on the side) which are not reported here. Full details can be found in Robben et al. (1989).

\section{Results}

The results consist of three parts. First, we provide some information on the correspondence of self-reported and official fraud. The next section is a simple univariate comparison between the honest and fraudulent individuals as defined by the authorities and as defined by themselves. Finally, we present regression analyses to identify the best predictors of (a) fraud according to the authorities and (b) self-reported fraud. Though multivariate structural analysis would, in principle, provide a better test of our model we have not used this form of analysis as the number of cases is modest compared with the number of relationships that should be estimated. This makes this form of a nalysis vulnerable to stray findings. In this way we try to avoid the pitfall of overinterpreting associations that may not survive an analysis with more observations.

Table 1 compares self-reported fraud with officially defined fraud. It is clear that the majority of the respondents reported their fraud status accu- 
Table 1

Self-Reported Misuse of the Allowance Compared with the View of the Unemployment Agency

\begin{tabular}{|c|c|c|c|}
\hline \multirow[t]{2}{*}{ Self-report } & \multicolumn{2}{|c|}{$\begin{array}{c}\text { Fraud status according } \\
\text { to the agency }\end{array}$} & \multirow{2}{*}{ total } \\
\hline & no fraud & fraud & \\
\hline Denied having received an allowance & 8 & 8 & 16 \\
\hline [no fraud] & $16 \%$ & $18 \%$ & $17 \%$ \\
\hline Had no additional income & 29 & 7 & 36 \\
\hline [no fraud] & $57 \%$ & $16 \%$ & $38 \%$ \\
\hline Reported additional income & 9 & 4 & 13 \\
\hline [no fraud] & $18 \%$ & $9 \%$ & $14 \%$ \\
\hline Did not report additional income & 5 & 26 & 31 \\
\hline [fraud] & $10 \%$ & $58 \%$ & $30 \%$ \\
\hline Total & 51 & 45 & 96 \\
\hline
\end{tabular}

Note. Percentages are with respect to column totals.

Kendall's tau rank correlation coefficients, after dichomizing the self-report into fraud/no fraud are 0.51 (total table) and 0.60 (omitting first row).

rately, though five of the supposedly honest group had earned money on the side (and not been detected) and 11 of the fraudulent group claimed never to have committed fraud. Even more striking is that 16 respondents claimed not to have had any unemployment benefit.

Given that there is a good correspondence between the official view and the view of the respondents themselves, it is unsurprising that simple univariate comparisons between the honest and fraudulent groups give very similar results whether membership of these groups is defined by the authorities or by self-reports. Table 2 presents the means for the various measures. It is evident that lower income does not lead to fraud; though the differences are not significant, the honest group has a lower unemployment benefit and had lower income previously. However, income per se is probably a poor operationalization of financial strain and possibly the greater drop in income of the fraudulent group would result in more financial difficulties. It is interesting, in this context, that the fraudulent group do make a more unfavorable comparison between their current benefit and their previous earnings than the honest group.

There is no evidence that social norms are encouraging fraud (though the 


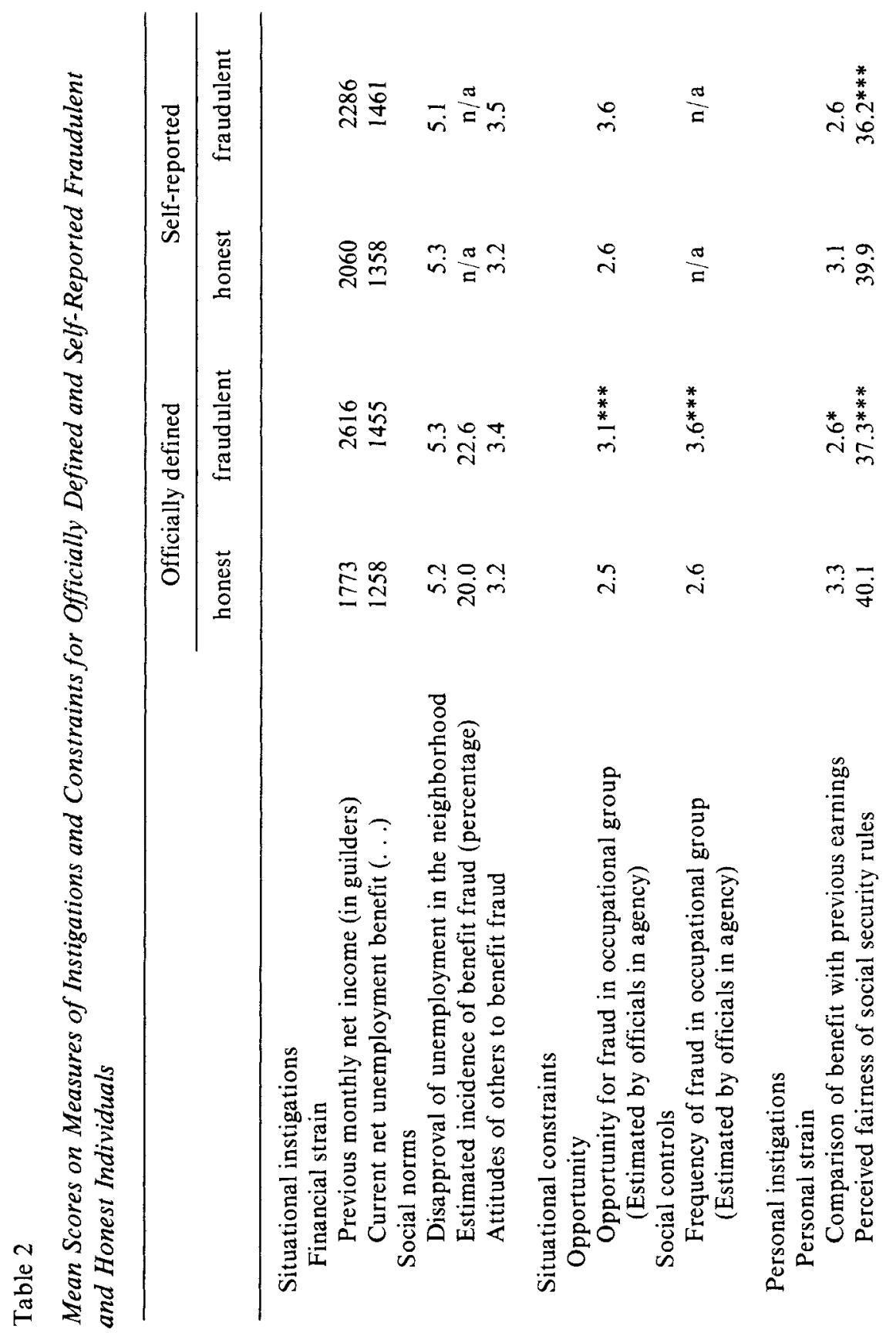




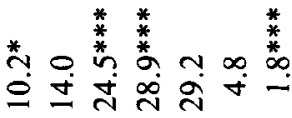

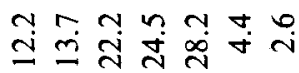

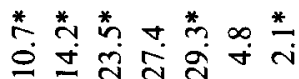

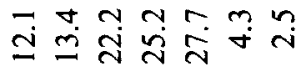

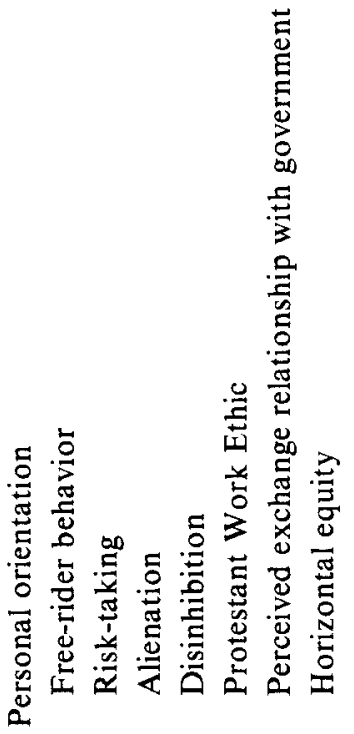

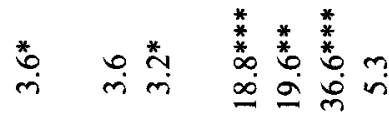

จิำำ

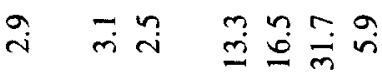

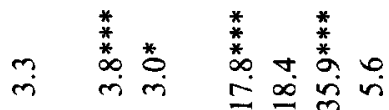

$\stackrel{a}{i} \stackrel{m}{\underline{i}} \stackrel{0}{\dot{D}} \vec{m}$

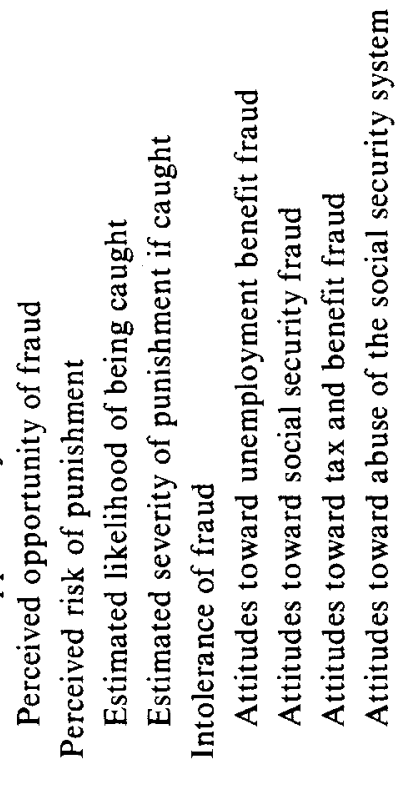

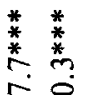

กู้ ?

n̊ㅇํㅇ

$\therefore 0$

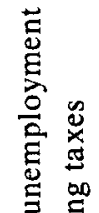

पे

$\stackrel{8}{3}$

守

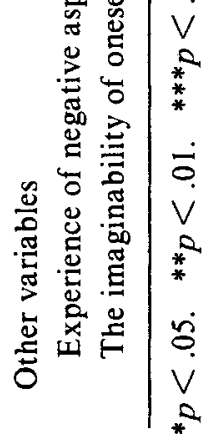


differences between the two groups are all in the expected direction). On the other hand, according to the officials in the agency, the occupations of those in the fraudulent group do provide a greater opportunity for fraud. Only some of the measures of personal orientation differentiate the two groups: The most intriguing finding is that the fraudulent group have a higher score on the Protestant Work Ethic scale. The measures of personal constraint reveal several differences. Fraudsters have a more tolerant attitude toward all kinds of fraud and estimate the chances of being caught (and the severity of punishment) as higher, presumably the result of their having been caught and punished.

The univariate comparisons give an idea of how the fraudulent and honest groups differ, but are not a good way of testing the theoretical model presented above. Ideally, one would like to fit a linear structural model, but the number of cases is small in comparison with the number of variables and so the power of a fitting technique would be unacceptably low. To give some idea of how well the variables can be used to predict fraud two regression analyses were carried out, using variables from Table 1 as independent measures and official and self-reported fraud status as the dependent measures. Table 3 presents the results of these analyses. Four variables are able to explain $45 \%$ of the variance in officially defined fraud, namely, the frequency of fraud in occupational group, perceived chance of being caught, attitude toward unemployment benefit fraud, and the imaginability of oneself evading taxes. Less of the variance of self-reported fraud can be explained (31\%) and with a different set of four variables (the frequency of fraud in the occupational group again, disinhibition, perceived fairness of social security rules and attitude toward abuse of the social security system.

\section{Discussion}

These results are clearly limited by the comparatively small scale of the investigation, the relatively poor response rate, and the fact that our classification of individuals as fraudulent or honest is not watertight. Some fraudulent individuals are found in the "honest" group, and it is possible that the official records have erroneously categorized people as committing fraud. Nonetheless, we can be sure that the fraud group are more fraudulent than the honest group and the fact that there are no significant differences between respondents and nonrespondents in the fraud group on a number of indices make us confident that this sample is representative.

Our initial hypothesis was that personal constraint measures would predict self-reported fraud but be unrelated to documented fraud and that personal instigation measures would be correlated with documented fraud but not self-reported fraud. This is clearly not the case; both types of vari- 
Table 3

Variables Predicting Fraud

\begin{tabular}{llllll}
\hline & $R$ & $R^{2}$ & $\beta$ & $\alpha$ & $r$ \\
\hline
\end{tabular}

(a) With officially defined fraud as the dependent variable

$\begin{array}{llllll}\text { Frequency of fraud in occupational group } & .46 & .21 & .31 & .000 & .46\end{array}$ [social control]

Attitudes toward unemployment benefit fraud

[intolerance of fraud]

Estimated likelihood of being caught

[risk of punishment]

$\begin{array}{llllllllll}\text { Imaginability of self evading taxes } & & & .67 & .45 & .20 & .016 & .33\end{array}$

(b) With self-reported fraud as the dependent variable

$\begin{array}{llllll}\text { Perceived fairness of social security rules } & .38 & .15 & -.28 & .000 & -.38\end{array}$ [personal strain]

Disinhibition

[personal orientation]

$\begin{array}{llllll}\text { Frequency of fraud in occupational group } & .52 & .27 & .34 & .031 & .31\end{array}$ [social control]

$\begin{array}{lllll}.55 & .30 & .30 & .001 & .39\end{array}$

$\begin{array}{lllll}.64 & .41 & -.34 & .001 & -.37\end{array}$

Attitude toward abuse of the social security system

[intolerance of fraud]

Note. $R=$ Multiple correlation coefficient. $R^{2}=$ Squared multiple correlation coefficient (explained variance). $\beta=$ Standardized regression coefficient. $\alpha=$ Significance level. $r=$ Pearson correlation coefficient with dependent measure.

ables predict both types of fraud. Here the correspondence between official and self-reported behavior is much higher than in comparable studies of illegal behavior (cf. Hessing et al., 1987). This is probably because the behavior (working while receiving benefit) is much clearer for both the authorities and the individual than a more diffuse behavior like tax evasion, where questions of intent are important and the behavior is probably defined differently by the authorities and individuals.

The picture of those who fraudulently claim unemployment benefit confirms and extends the results of Renooy (1990) and Elffers and Hessing (1990) and provides some support for the model of Weigel et al. (1987). The 
kinds of variables that their model highlights certainly seem to be important, though it has to be admitted that social instigations seem to play a weak role. For officially measured behavior situational and personal constraints are the best predictors; for self-reported behavior, personal instigations are also important. Perhaps equally significant are the variables that fail to differentiate the two groups, most notably competitive social orientation. On the other hand, the results suggest that social security fraud in Holland may have a distinctively Dutch flavor. Though the evidence is very poor (essentially occasional references in case studies) Kelvin and Jarrett (1985) claim that informal economic activity by the unemployed in Britain is not internalized; it may help financially but it has an ephemeral quality with less salience than a real job. Our research, and that of Renooy (1990), implies that, for some Dutch people at least, working on the side is a way of life.

From the authorities' point of view the applied relevance of this research is what it tells us about preventing or limiting fraud. As far as personal orientation is concerned, there seems little room for maneuver. Personal orientation is relatively stable and not easily changed. However although from the perspective of fraud prevention the personal orientations of the fraudsters may be worrying, from the perspective of unemployment prevention the higher work ethic of the fraudsters is encouraging. With changes in the social security system, that allow those on unemployment benefit to work these people would be an asset. Attitudes look like a better prospect for change but we have our doubts. It seems likely, on the basis of previous research, that people bring their attitudes in line with their behavior and so the positive attitudes of the fraudsters toward fraud may merely reflect the fact that they are, after all, fraudsters. Punishment is the traditional way of dealing with crime, but here, at least, it seems to have little deterrent effect. A more draconian system, with better detection and heavier punishment may deter people from benefit fraud but one suspects that using legal means to hit at those at the bottom of the social pile may be socially unacceptable. Finally we come to opportunity. Just as in tax evasion research, opportunity is a crucial variable. But on the face on it there seems little the authorities can do about this.

We believe that we have shown that it is both possible and fruitful, through a combination of official data with self-report data, to go some way to understanding the determinants of unemployment benefit fraud. This research is only a beginning and has some obvious limitations. But it provides a firm basis for future research.

\section{References}

Condie, S. J., Warner, W. K., \& Gillman, D. C. (1976). Getting blood from collective turnips: volunteer donation in mass blood drives. Journal of Applied Social Psychology, 61, 290-294. 
Elffers, H., \& Hessing, D. J. (1990). Houding jegens belastingontduiking en uitkeringsmisbruik [Attitudes toward tax evasion and benefit abuse]. In Sociale Zekerheidsfraude: mede bezien in het licht van belastingfraude [Social security fraud, also seen in the light of tax evasion] (pp. 20-27). Rotterdam: Erasmus University, Faculteit der Rechtsgeleerdheid.

Elffers, H., Weigel, R. H., \& Hessing, D. J. (1987). The consequences of different strategies for measuring tax evasion behaviour. Journal of Economic Behaviour, 8, 311-337.

Friedland, N. (1985). Variable credibility threats: A procedure for the enhancement of deterrence effectiveness. Journal of Applied Social Psychology, 15, 230-236.

Furnham, A. (1985a). The determinants of attitudes towards social security recipients. British Journal of Social Psychology, 24, 354-373.

Furnham, A. (1985b). Why do people save?: Attitudes to and habits of saving money in Britain. Journal of Applied Social Psychology, 15, 354-373.

Golding, P., \& Middleton, S. (1978). Why is the press so obsessed with welfare scroungers? New Society, 46, 195-197.

Golding, P., \& Middleton, S. (1982). Images of welfare. Oxford: Martin Robertson.

Hauber, A. R., Toornvliet, L. G., \& Willemse, H. M. (1986). Persoonlijkheid en criminaliteit bij scholieren [Personality and criminality in schoolchildren]. Tijdschrijft voor Criminologie, 2, 92-106.

Hessing, D. J., \& Elffers, H. (1985). Economic man or social man? In H. Brandstätter \& E. Kirchler (Eds.), Economic psychology (pp. 195- 203). Linz: Trauner.

Hessing, D. J., Elffers, H., Robben, H. S. J., \& Webley, P. (1991). The social psychology of unemployment benefit fraud. Internal report, Erasmus Centre for Socio-Legal Tax Research.

Hessing, D. J., Elffers, H., \& Weigel, R. H. (1988). Exploring the limits of self-reports and reasoned action: an investigation into the psychology of tax evasion behavior. Journal of Personality and Social Psychology, 54, $405-413$.

Hessing, D. J., Kinsey, K. A., Elffers, H., \& Weigel, R. (1988). Tax evasion research: Measurement strategies and theoretical models. In W. F. Van Raaij, G. M. Van Veldhoven, \& K-E Wärneryd (Eds.), Handbook of economic psychology (pp. 516-537). Dordrecht: Kluwer.

Jackson, D. N. (1976). Jackson Personality Inventory (Manual). Goshen, NY: Research Psychologists Press.

Kazemier, B., van Eck, R., \& Koopmans, C. C. (1990). Economische aspecten van belasting- en premie ontduiking en misbruik van sociale uitkeringen. [Economic aspects of tax-and insurance contribution evasion and social benefit abuse]. In D. J. Hessing \& H. P. A. M. van Aren- 
donk (Eds.), Sociale-Zekerheidsfraude: Juridische, economische en psychologische aspecten van fraud in het sociale-zekerheidsstelsel [Social security fraud: Legal, economic and psychological aspects of fraud in the social security system] (pp. 123-190). Deventer: Kluwer.

Kelvin, P., \& Jarrett, J. E. (1985). Unemployment: Its social psychological effects. Cambridge: Cambridge University Press.

Kingston, J. L., Burgess, P. L., \& St. Louis, R. D. (1981). Overpayments in the unemployment insurance system in the United States. International Social Security Review, 34, 462-476.

Kingston, J. L., Burgess, P. L., \& St. Louis, R. D. (1986). Unemployment insurance overpayments: Evidence and implications. Industrial Labor Relations Review, 39, 323-336.

Liebrand, W. B. G. (1982). Interpersonal differences in social dilemmas: $A$ game theoretic approach. Unpublished doctoral dissertaion, State University of Groningen.

Liebrand, W. B. G., Messick, D. M., \& Wilke, H. A. M. (1991). A social psychological approach to social dilemmas. Oxford: Pergamon.

Loveland, I. (1989). Policing welfare and local authority responses to claimant fraud in housing benefit schemes. Journal of Law and Society, 16, 187-209.

McClintock, C. G., \& Allison, S. T. (1989). Social value orientation and helping behaviour. Journal of Applied Social Psychology, 19, 353-362.

Mirels, H. L., \& Garett, J. B. (1971). The protestant work ethic as a personality variable. Journal of Consulting and Clinical Psychology, 36, 40-44.

Newman, G. (1976). Comparative deviance; perception and law in six cultures. Amsterdam: Elsevier.

Renooy, P. H. (1990). The informal economy: Meaning, measurement and social significance. Amsterdam: Regioplan.

Robben, H. S. J., Elffers, H., \& Verlind, W. F. M. (1989). Determinanten van individueel misbruik van sociale verzekeringen: het geval van wwmisbruik [Determinants of individual abuse of social security: The case of unemployment benefit abuse] (Report No. R89-02). Amsterdam: Federatie van Bedrijfsverenigingen.

Roth, J. A., Scholz, J. T., \& Witte, A. D. (1989). Taxpayer compliance, Vol 1: An agenda for research. Philadelphia: University of Pennsylvania Press.

Smith, K. W., \& Kinsey, K. A. (1987). Understanding taxpaying behavior: A conceptual framework with implications for research. Law and Society Review, 21, 639-663.

Smith, S. (1986). Britain's shadow economy. Oxford: Clarendon Press.

Social Security News. (1987). Restructuring the Dutch unemployment compensation scheme. International Social Security Review, 40, 299-301. 
Webley, P., Levine, R. M., \& Lewis, A. (1991). A study in economic psychology: children's saving in a play economy. Human Relations, 44, $127-$ 146.

Weigel, R. H., Hessing, D. J., \& Elffers, H. (1987). Tax evasion research: A critical appraisal and a theoretical model. Journal of Economic Psychology, 8, 215-235.

Yaniv, G. (1986). Fraudulent collection of unemployment benefits: A theoretical analysis with reference to income-tax evasion. Journal of Public Economics, 30, 369-383.

Zeller, R. A., Neal, A. G., \& Groat, H. T. (1980). On the reliability and stability of alienation measures: A longitudinal analysis. Social Forces, 58, 1195-1204.

Zuckerman, M. (1979). Dimensions of sensation seeking: Beyond the optimal level of arousal. Hillsdale, $\mathrm{NJ}$ : Erlbaum. 